\title{
The Impact Of Inflation, US Dollar Exchange Rate And Land Transportation Freight Towards Non-Oil And Natural Gas Export To America, Japan, Australia And England Through Surabaya Port In The Year of 2015-2017
}

\author{
Murpin Josua Sembiring \\ WidyaKartika University, Surabaya \\ Herman Budi Sasono \\ WidyaKartika University, Surabaya
}

\begin{abstract}
Indonesia is one of the countries which frequently administer both export and import activities with many countries in the world. Export activities done by Indonesia are influenced by non-oil and natural gas export. This research analyses the impact of inflation, US Dollar exchange rate, and land transportation freight towards non-oil and natural gas export activities to America, Japan, Australia, and England through Surabaya Port in the year of 2015 to 2017. Furthermore, this research uses quantitative method and the data collected are gathered from secondary. The data analysis used in this research is multiple linear regressions. The result of this research shows that all independent variables which are inflation $\left(X_{1}\right)$, US Dollar exchange rate $\left(X_{2}\right)$, and land transportation freight $\left(\mathrm{X}_{3}\right)$ bring non-significant impact towards non-oil and natural gas export to four countries mentioned before. However, in the non-oil and natural gas export activities to Australia, the US Dollar exchange rate variable $\left(\mathrm{X}_{2}\right)$ brings significant impact. Meanwhile, land transportation freight variable $\left(X_{3}\right)$ is significant towards the export activities to England.
\end{abstract}

Keywords: inflation, US Dollar exchange rate, land transportation freight, non-oil and natural gas export.

\section{INTRODUCTION}

There is no country in this world which is able to fulfill its citizens' needs both in general and industrial sectors which cover factory machinery, spare parts, raw and supporting materials, skilled laborswho have to be recruited from other countries. There is also no country in this world which has domestic marketthat is able to absorb all kinds of production output in agriculture, mining, industry, and fishery sectors. Thus, the over production on those sectors have to be exported to other countries. This export activity is performed to maintain the output continuity and productivity from those sectors. Besides, foreign market can be considered to have wider potency and better price compared to domestic market. In addition, this export transaction is able to encourage and support domestic production to improve the product quality continually to be able to compete in international market.

There are many countries which rely on their foreign exchange which they get from the export activities. This foreign exchange is used to fund their import activities and pay positive and private debts, as well as government debt towards creditors abroad. Export commodity can be divided into two big groups. The first group is oil and natural gas export which covers raw and ready-to-use oil, including LPG commodity while the second group which is non-oil and natural gas covers 1) industrial and manufactured products: textile, television, vehicles, medicine, furniture, 2) fishery products:crabs, shrimps, lobsters, milkfish, goldfish, nile tilapia, iridescent 
shark, 3) agriculture products: rice, corn, wheat, soybean, ricebrand, and 4) mining products:coal, gold, bauxite, iron ore, tin ore, and many more.

In Indonesia, those export products are one of sources which fill Indonesia's foreign exchange reserve, while the other sources are loans or debts from other countries or international monetary sources such as IBRD (International Bank for Reconstruction and Development), IMF (International Monetary Fund), and also foreign investment. It also includes foreign credits and securities which are planted overseas (stock and debenture) which have been bought from foreign companies.

Sand export commodity is also highly taxed since sand cannot be reproduced except 1) sand from rivers which depends on natural gift and river stream, 2) sand from mountain which is brought by cold lava from erupted volcanoes; meanwhile, on the other hand, this sand is needed by domestic consumers for physical development. The other "arranged" export commodities are products from coffee plantation, pult industry, diamond mine, and manufactures. Export monitored goods are goods which are also needed domestically. The monitoring is performed to maintain domestic trading and consumption stability and nature conservation, and to fulfill and support industrial development domestically. On the other hand, some goods are prohibited to be exported to maintain Indonesia nature conservation or the goods have not fulfilled international quality standard and to secure domestic materials need for small industries, small scale craftsmen, and those goods have high cultural values. Free exported goods are goods needed for product and market diversification, and the export activity can be done by fulfilling general requirement as exporters.

\section{LITERATURE REVIEW}

\section{Inflation}

Definitively, inflation is a situation or condition in which the price of goods and services has a tendency to increase continually. Tthe price increase of some goods such as eggs, wheat flour, sugar, and butter approaching Christians' holidays, Christmas, or Moslems holidays, Eid Mubarak, and the end of the year between December to January. However, it is not inflation since the price is only temporary increased and after those days the market demand will decrease. Specifically, the corruption level in almost every aspect in Indonesia can be considered high and difficult to be eradicated. This kind of illegal charges causes the increase of production cost which also causes the increase of goods and services price. The government's policy in increasing oil and gas price (BBM) has also caused the increase of variable cost from industry sector both producers and factories.

\section{Exchange Rate}

Exchange rate is the value of a foreign currency compared to domestic currency (Simorangkir, 2004). There are two conditions regarding a country's exchange rate. The first is depreciation in which Indonesian Rupiah (IDR) exchange rate becomes stronger compared to foreign currency and appreciation if the IDR exchange rate becomes weaker. There are many government policies to control its exchange rate. It is caused by the fact that it can influence any activity in the country including economy activity. Exchange rate influences purchasing and sales upon certain products both goods and services in a country.

Exchange rate also influences export and import activities. If a country's currency exchange rate is weaker than the producer's country, the import expense is greater and society 
purchasing ability will also decrease. It will also affect the country's economy activities nationally.

There are two kinds of policy in dealing with the country's currency exchange, revaluation and devaluation. Revaluation is a policy which is made by the government to increase its currency towards foreign exchange rate. Devaluation is government's policy to decrease its currency towards foreign exchange rate. The increase and decrease of a currency exchange rate are influenced by many demand and offer factors.

\section{Land Transportation Freight}

According to Tjakranegara (1995:15), the reason why there are many transportation companies is because every capable person is able to establish a transportation company. The first capital in land transportation business is not too big (a colt diesel truck costs IDR 235.000.000,-)if it is compared to water transportation (a new transport ship costs IDR 250 billion per unit). Not every person is able to establish water-transportation company.A ship costs hundreds of billion and it is called as free entryin land-transportation companies. The difference occurs between land and ocean transportation companies can be considered normal. Each company can be established individually as private business.The capital needed for other close beach/ocean, air, and train transportation companies can be considered huge. This problem is understandable.

\section{Hypothesis}

$\mathrm{H}_{1}$ : Inflation level's significant impact towards non-oil \& natural gas export

$\mathrm{H}_{1.1}$ : Inflation level's significant impact towards non-oil \& natural gas exportto America

$\mathrm{H}_{1.2}$ : Inflation level's significant impact towards non-oil \& natural gas export to Japan

$\mathrm{H}_{1.3}$ : Inflation level's significant impact towards non-oil \& natural gas exportto Australia

$\mathrm{H}_{1.4}$ : Inflation level's significant impact towards non-oil \& natural gas export to England

$\mathrm{H}_{2}$ : US Dollar exchange rate's significant impact towards consumption materials import

$\mathrm{H}_{2.1}$ : US Dollar exchange rate's significant impact towards non-oil \& natural gas export to America

$\mathrm{H}_{2.2}$ : US Dollar exchange rate's significant impact towards non-oil \& natural gas export to Japan $\mathrm{H}_{2.3}$ : US Dollar exchange rate's significant impact towards non-oil \& natural gas export to Australia

$\mathrm{H}_{2.4}$ : US Dollar exchange rate's significant impact towards non-oil \& natural gas export to England

$\mathrm{H}_{3}$ : Land Transportation Freight cost's significant impact towards non-oil \& natural gas export

$\mathrm{H}_{3.1}$ : Land Transportation Freight cost's significant impact towards non-oil \& natural gas export to America

$\mathrm{H}_{3.2}$ : Land Transportation Freight cost's significant impact towards non-oil \& natural gas export to Japan

$\mathrm{H}_{3.3}$ : Land Transportation Freight cost's significant impact towards non-oil \& natural gas export to Australia

$\mathrm{H}_{3.4}$ : Land Transportation Freight cost's significant impact towards non-oil \& natural gas export to England

$\mathrm{H}_{4}$ : Difference in non-oil \& natural gas export to America, Japan, Australia, and England

\section{Research type}

\section{RESEARCH METHOD}

This research is causal since both independent and dependent variables are related each other. According to Sugiyono (2014), causal is a cause-effect relation between independent variable 
(cause) and dependent variable (effect). This research is quantitative research which uses numbers and statistics as the data (Sugiyono, 2014).

\section{Data Collection Technique}

The data collected in this research is take from secondary source which is library research and documentation. Library research is an analysis technique to gather data from notes, literature, and other relevant sources and the documentation procedure is done by browsing and documenting the data and every information related to the study object.

\section{Operational Variable Definition and Measurement Dependent Variable}

The dependent variable used in this research is non-oil \& natural gas export (Y). this variable is measured using non-oil \& natural gas export data from America, Japan, Austraila and England from 2015 to 2017.

\section{Independent Variable}

1. Inflation

Inflation is the process of continual price increase. In this research, the data is taken from the inflation suffered by Indonesia from 2015 to 2017.

2. US Dollar exchange rate

Exchange rate is a present or future standard currency exchange rate between two countries. This research uses US Dollar exchange rate towards IDR from 2015 to 2017.

3. Land Transportation Freight

Land Transportation Freight is the rates used to load and transport goods from places such as port. The data used in this research is taken from Surabaya Port land transportation freight rates from 2015 to 2017.

\section{Data Analysis Technique}

This research uses multiple linear regressions to prove the impact of inflation, US Dollar exchange rate, and land transportation freight towards non-oil \& natural gas export to America, Japan, Australia, and England. Multiple linear regressions is used to analyze the condition (up and down) the dependent variable (criterion) if there are two or more independent variablesas manipulated predictor factors (the value is increased and decreased) (Sugiyono, 2014). Besides, this research also uses difference test to analyze the difference in non-oil \& natural gas export in each country: America, Japan, Australia, and England.

FINDINGS AND DISCUSSION

Multiple Linear Regressions Analysis Finding

Table 1. Multiple Linear Regressions Analysis Finding

\begin{tabular}{|l|c|c|c|c|}
\hline \multirow{2}{*}{ Variables } & \multicolumn{4}{|c|}{ Consumption Materials Import (Food and Drinks) (Y) } \\
\cline { 2 - 5 } & USA(Y1) & Jepang(Y2) & Australia (Y3) & Inggris (Y4) \\
\hline Inflation (X1) & 0,346 & 0,126 & 0,104 & 0,591 \\
\hline $\begin{array}{l}\text { USD Exchange Rate } \\
\text { (X2) }\end{array}$ & 0,897 & 0,912 & $0,027^{*}$ & 0,139 \\
\hline $\begin{array}{l}\text { Land } \\
\begin{array}{l}\text { Transportation } \\
\text { Freight (X3) }\end{array}\end{array}$ & 0,642 & 0,604 & 0,544 & $0,001^{* *}$ \\
\hline
\end{tabular}


Multiple Linear Regressionsanalysis findingshows that the whole independent variables which are inflation, USD exchange rate, and land transportation freight do not affect non-oil \& natural gas export to America, Japan, Australia, and England significantly. On non-oil \& natural gas export to Australia, US Dollar exchange rate affects significantly while land transportation freight brings significant impact towards non-oil \& natural gas export to England.

Table 2. Difference Test Finding

\begin{tabular}{|c|c|c|c|}
\hline Levene Statistic & df 1 & df 2 & Sig \\
\hline 2,441 & 2 & 33 & 0,013 \\
\hline
\end{tabular}

The difference test finding shows significance value 0,013 which is smaller than 0,05 . It means that there are differences in non-oil \& natural gas export to America, Japan, Australia and England.

\section{Hypothesis Result \\ Hypothesis Test 1}

The first hypothesis can be proved. The data analysis shows $t=-41,156$ which is smaller than 1,689. It can be considered that the Inflation Level brings significant impact towards oil \& natural gas export. However, the value of inflation towards non-oil \& natural gas export shows low score which is 0,162 . It can be concluded that the influence of inflation level towards nonoil \& natural gas export is not too high. The influence value of inflation towards non-oil \& natural gas exportis 0,238 which is in negative direction. The higher the inflation level is, the lower non-oil \& natural gas activities are done.

Multiple Linear Regressions Analysis Result shows that hypotheses H1.1, H1.2, H1.3, H1.4 are not proved its validity since the data analysis result shows the values of $t$ for America, Japan, Australia, and England are smaller than the table's t value $(0,9<1,69 ; 1,57<1,69 ; 1,67<1,69$; $0,54<1,69$ ). It means that the inflation independent variable does not bring significant impact towards non-oil \& natural gas export to America, Japan, Australia, and England.

\section{Hypothesis Test 2}

The second hypothesis is validly proved. The value of $t$ is $-39,961$ which is smaller than $-1,689$. It can be concluded that the exchange rate brings significant impact towards oil \& natural gas export. However, the level of significance between inflation and non-oil \& natural gas export is very small which is. It can be concluded that the impact of exchange rate towards non-oil \& natural gas export is not too high. The value of exchange rate towards non-oil \& natural gas exportis 0,099 with positive direction which means the higher the exchange rate is, the higher the non-oil \& natural gas exportactivities are done.

Multiple linear regressions analysis result shows that hypotheses H2.1, H2.2, H2.4 are not validly proved since the data analysis result shows that $t$ value for America, Japan, and England is smaller than the table's t value $(0,13<1,69 ; 0,112<1,69 ; 1,5<1,69)$. Therefore, it can be said that independent variable exchange rate brings no significant impact towards non-oil \& natural gas exportto America, Japan, and England. On the other hand, hypothesis $\mathrm{H} 2.3$ is validly proved where the data analysis shows Australia's t valueis bigger than the table's $t(2,5>1,69)$. Hence, it can be considered that the exchange rate brings significant impact towards non-oil \& natural gas export to Australia.

\section{Hypothesis Test 3}

The third hypothesis in this research is validly proved since the data analysis shows $t=36,152$ which is bigger than 1,689. It can be concluded that land transportation freight brings 
significant impact towards oil \& natural gas export. However, the significance level between land transportation freight and non-oil \& natural gas exportshows low value which is 0,52 . It can be concluded that the impact brought by land transportation freight towards non-oil \& natural gas exportis not too big. It shows the value of 0,112 with positive direction. The higher land transportation freight is, the more non-oil \& natural gas exportactivities are done.

Multiple linear regressions analysis result shows hypotheses H3.1, H3.2, H3.3, are not validly proved since the data analysis result shows that the value of $t$ of America, Japan, Australia is smaller than table's $t(0,47<1,69 ; 0,52<1,69 ; 0,61<1,69)$. It can be concluded that land transportation freight does not bring significant impact towards non-oil \& natural gas exportto America, Japan and Australia. On the other hand, the multiple linear regressions analysis result on H3.4 shows valid proof since it shows $t$ value for England is bigger than table's $t \quad 3,48>$ 1,69). It can be concluded that land transportation freight variable brings significant impact towards non-oil \& natural gas exportto England.

\section{Hypothesis Test 4}

The fourthhypothesis in this research is validly proved since the data analysis shows significance value $=0,013$ which is smaller than 0,05 . It can be concluded that there are differences in non-oil \& natural gas exportto America, Japan, Australia, and England.

\section{DISCUSSION}

Based on the collecteddata analysis result, it can be seen that inflation level brings significant impact towards non-oil \& natural gas exportshown by $t=-41,156$ which is smaller than $-1,689$. The impact of those two variables shows negative direction, 0,238 which means that the higher the inflation level is, the lower non-oil \& natural gas exportare done and vice versa.It is caused by too high or low production cost since inflation level can make the producer not be able to decide suitable and stable price for the international market. Unstable inflation level also causes non-oil \& natural gas exportactivity limitation since there is no certainty about its feedback towards economy growth in Indonesia.The multiple linear regressions result shows the inflation level brings no significant impact towards non-oil \& natural gas exportto America, Japan, Australia, and England.

The data analysis also shows that exchange rate brings significant impact towards non-oil \& natural gas exportshown by t value $=-39,961$ which is smaller than $-1,689$. The impact of those two variables show positive direction 0,099 which means that the higher the exchange rate is, the more non-oil \& natural gas exportactivities are done, vice versa. It shows that IDR exchange rate towards US Dollar can influence non-oil \& natural gas exportactivity in Surabaya Port.Multiple linear regressions result shows t value for Australia is bigger than table's t (2,5> $1,69)$. It can be concluded that exchange rate variable brings significant impact towards non-oil \& natural gas exportto Australia.

The data analysis also shows that land transportation freight brings significant impact towards non-oil \& natural gas exportshown by t value $=36,152$ which is bigger than 1,689 . The impact of those two variables show positive direction 0,112 which means that the higher the land transportation freight is, the more non-oil \& natural gas exportactivities are done, vice versa. It shows that land transportation freight can influence non-oil \& natural gas exportactivity in Surabaya Port.Multiple linear regressions result shows t value for England is bigger than table's $t(3,48>1,69)$. It can be concluded that land transportation freight variable brings significant impact towards non-oil \& natural gas exportto England. The difference test result 
shows that non-oil \& natural gas export activities to America, Japan, Australia, and England are different.

\section{Conclusion}

\section{CONCLUSION AND SUGGESTIONS}

Basedonthe data analysis result, it can be concluded that:

1. Inflation level brings significant impact with negative direction towards non-oil \& natural gas export. However, inflation level does not bring significant impact towards non-oil \& natural gas exportto America, Japan, Australia and England which were done in Surabaya Port from 2015 to 2017.

2. The increase of US Dollar exchange rate towards IDR brings significant impact towards non-oil \& natural gas exportwith positive direction. US Dollar exchange rate towards IDR only brings significant impact towards non-oil \& natural gas exportactivities to America, Japan, Australia and England in Surabaya Port from 2015 to 2017.

3. Land transportation freight brings significant impact towards non-oil \& natural gas exportwith positive direction. However, among these 4 countries, the significant impact only happens in dealing with non-oil \& natural gas exportactivities to England in Surabaya Port from 2015 to 2017.

4. The difference test result shows that there are differences among non-oil \& natural gas exportactivities to America, Japan, Australia and England which were done through Surabaya Port from 2015 to 2017.

\section{Suggestions}

1. By looking at significant impact brought by inflation level towards non-oil \& natural gas exportactivities, government, especially Bank of Indonesia must try to suppress and anticipate the increase of inflation level by using its instruments such as: Credit Policy/Loan Policy, Cash Ratio/Reserve Requirement Policy, and also new currency control so that the supply of moneyand domestic goods availability can be balanced.

2. IDR exchange rate towards US Dollar must be maintained on normal level so that it can encourage non-oil \& natural gas exporters to increase their export volume especially to Australia where the US Dollar exchange rate brings impact towards non-oil \& natural gas exportactivities of Indonesia (based on this research). Therefore, the exchange rate must be maintained so it will not pass the normal limit. If the IDR exchange towards US Dollar is decreased, the government must intervene by supplying/dropping US Dollar to the market.

3. Since the capital of land transportation is trucks which transport exported goods from factories/producers to Surabaya Port and imported goods from Line I from Surabaya Port to factories/producers, it can be considered that those trucks are as important as the ships which transport exported goods. On the other words, those trucks play important roles to decide the flow of goods in Surabaya Port. This result shows that the up and down of land transportation freight brings significant non-oil \& natural gas exportactivities to those 4 countries. Multiple linear regressions even shows that it brings the most significant impact towards non-oil \& natural gas exportactivities to England.

4. Because this research also uses difference test which shows that there are activities differences which means different export activities volume towards America, Japan, Australia and England, the government must make policies which can be implemented to support, encourage, and increase the non-oil \& natural gas exportactivities to those 4 countries. 
Sembiring, M. J., \& Sasono, H. B. (2018). The Impact Of Inflation, US Dollar Exchange Rate And Land Transportation Freight Towards Non-Oil And Natural Gas Export To America, Japan, Australia And England Through Surabaya Port In The Year Of 2015-2017. Archives of Business Research, 6(12), 337-344.

\section{References}

Administrator Pelabuhan Tajung Perak Surabaya. 2017. Data Kunjungan Kapal dan Kegiatan Bongkar Muat di Pelabuhan Tanjung Perak Surabaya. Period 2015-2017.

Djarwanto. 2001. Mengenal Beberapa Uji Statistik Dalam Penelitian. Edisi Kedua. First Print. Yogyakarta: Liberty. Act of Directors of (PERSERO) Pelabuhan Indonesia III Company Surabaya (2015).

Act of Indonesia Transportation Ministry Number: KM. 62 year 2002 About Organization and Working Procedure of Port Administration Office (2003). Transportation Department Law Bureau.

Krugman, Paul R dan Maurice Obsfield. 1993. Ekonomi Internasional: Teori dan Kebijakan (Translator: Harismunandar dan Faisal Basri. Second Print. Jakarta: PT. Raja Grafindo Persada (d/h Rajawali Pers).

Monthly Magazine Dermaga. 2005. Edition 80, 81, 82 June, July, August 2005.

TPS Magazine, PT. Terminal Petikemas Surabaya. $5^{\text {th }}$ Anniversary Edition 2004.

Tanjung Perak Post Magazine. Suara Informasi Bisnis. Nomor 100/Th. V II Week of April 2005.

Nopirim. 1996. Ekonomi Internasional. $3^{\text {rd }}$ Edition.Yogyakarta: BPFE.

Purba, Radik. 1997. Angkutan Muatan Laut. I Edition. First Print. Jakarta: PT. Rineka Cipta.

Purba, Radik. 1997. Angkutan Muatan Laut. II Edition. First Print. Jakarta: PT. Rineka Cipta.

Purba, Radik. 1995. Asuransi AngkutanLaut. First Print. Jakarta: PT. Rineka Cipta. Jakarta.

Salvatore, Domonick. 2014. EkonomiInternasional. Jakarta: Salemba Empat.

Soegeng, Wartini. 2000. Pengukuran Kapal Indonesia. First Print. Bandung: PT. Refika Aditama.

Tanjung Perak. Port Directory. 2015. Pelabuhan Indonesia III Surabaya.

Tjakranegara, Soegijatna. 1995. Hukum Pengangkutan Barang dan Penumpang. Jakarta: PT. Rineka Cipta.

Triyanto, Djoko. 2005. Bekerja di Kapal. First Edition.Bandung: Mandar Maju. 